Thengani Ngwenya

Thengani Ngwenya is an Associate Professor and Director of the Centre for Excellence in Learning and Teaching, Durban University of Technology, Durban.

Email: ngwenyat@dut.ac.za
Symbolic self-translation in Bloke Modisane's Blame Me on History

\title{
Symbolic self-translation in Bloke Modis- ane's Blame Me on History
}

The article examines Modisane's self-portrayal in his autobiography, Blame Me on History (1963). The author argues that for Modisane autobiographical self-representation takes the form of a complex and multi-layered process of symbolic and metaphorical translation of (self) identity. Symbolic self-translation in Modisane's autobiography involves attempts by the narrator-protagonist to untangle the conundrum resulting from what is presented as an unbridgeable chasm between the kind of person he could have been in a country devoid of racial oppression and what he was forced to become in the racially segregated South Africa of the twentieth century. Central to the analysis of Modisane's chosen mode of self-portraiture is James Olney's notion of "metaphors of self" in terms of which the autobiographical self seeks to articulate its elusive ontological status through metaphors and symbols. The article also provides a critique of contradictions inherent in the ideology of liberal humanism which is presented as universally desirable in Modisane's autobiography. Keywords: alienation, identity, self-representation, South African literature, translation

"According to Fanon, the black man only claims an identity through approval from the world of whites, which creates a destabilizing double consciousness" Meredith Goldsmith (110).

\section{Introduction}

William "Bloke" Modisane belongs to the group of South African black writers and journalists commonly known as the Drum writers, who came to prominence in the 1950s and who at some stage in their careers worked for Drum magazine. This group includes such well-known South African writers as Es'kia Mphahlele, Can Themba, Lewis Nkosi, Casey Motsisi, Arthur Maimane and Todd Matshikiza.

Born in 1923, Modisane lived and was educated in a multiracial (but largely black) residential area near Johannesburg known as Sophiatown. This vibrant area, which was demolished by the apartheid government in the 1950s to make way for a white middle-class suburb —ironically, named Triomf, Afrikaans for "triumph" — provides the setting for Blame me on history (1963) and functions as an organising metaphor in the autobiography as a whole. In Modisane's autobiography, Sophiatown provides a fitting symbol for the psychological and emotional disintegration of the author's personality prior to his departure, on an exit permit, from South Africa in 1959. 
While working for Drum, Modisane published short stories and wrote music reviews for a local newspaper called the Golden City Post. His short fiction and his social commentaries in Drum-like his autobiography-reflect the attempts of a largely self-taught writer-intellectual to come to terms with feelings of alienation and powerlessness in the face of repressive and discriminatory legislation. Mark Sanders (107) in his book Complicities sub-titled The Intellectual and Apartheid (2002) alerts us to the precarious situation of the African intellectual in the South Africa of the 1950s:

On one level, to speak of a disaffected African intellectual is to speak of someone who has withdrawn from the object determined by more "natural" filial ties, only to be denied affection of the more desirable object put in its place. The disaffected African intellectual is, in the lore of the 1950s, usually a man. He is in love with the unattainable and denies "the community" for "individual" well-being.

As though confirming Sanders' diagnosis, Modisane (218) describes his situation as follows in his autobiography: "I am an eternal alien between two worlds; the Africans call me a 'Situation', by Western standards I am uneducated".

\section{Autobiographical self-portrayal as self-translation}

In this paper, I argue that the act of self-portrayal in Modisane's autobiography is essentially an act of symbolic translation, involving attempts by the author to explore the implications of what he sees as the discrepancy between the kind of person he would have been in a free country and what he was forced to become in a racially segregated South Africa. One of the direct consequences of this situation for Modisane is the unbearable condition of alienation, which is the central theme of his autobiography. For this reason, Blame Me on History is an intensely engaging and almost surrealistic narrative of self-analysis, in which Modisane attempts to create a semi-fictional narrator-protagonist whose qualities are in line with what Modisane considers to be his real aspirations, ideals and values. In the process of autobiographical self-representation, the reality of living in a black working-class residential area with a culture characterised by jazz music, movies, illicit beer-brewing, political unrest, and gangsterism, is contrasted with the desired condition of freedom and leisure represented in the book by the metaphor of whiteness. Thus, for the purposes of this paper, translation is taken to mean personal transformation in which the real is contrasted with the ideal, and the tensions inherent in this process. Kgomotso Masemola (8) captures some of the effects of these tensions on Modisane's bruised psyche as follows:

In Blame Me on History there is a counterpoint to the miscalculation of history, deftly registered in the use of popular culture and cultural memory as a continuity between representational temporality of South Africa and America's Hollywood "reality", or rather, between historical temporality and fictional non-temporality. This counterpoint lends 
itself to Bloke's attempts at gaining acceptance in the white world of South Africa, and in humanity, whilst insisting that he is black (p.140). Using Sartrean terms, I would say the value of black is the lack in relation to which the For-Itself determines being as a lack.

Although this understanding of translation is largely symbolic, it also has an important literal and linguistic dimension, as Modisane, whose mother tongue is Sesotho, chose to write in English-a language that, for Modisane, seems to have superseded his home language in value and significance. In the autobiography, he claims that he thinks in English; so what we are looking at is literal translation or transformation of consciousness or self-conception. The linguistic and, by extension, cultural dimension of this process of self-translation is not without its own challenges. The question of translating one's self by recreating the self in autobiography or in other literary forms has been tackled in an illuminating collection of critical essays collected in a book by Mary Besemers titled Translating One's Self (2002). Modisane's autobiography prompts the discerning reader to interrogate his status as a "language migrant". In this regard, Blame Me on History is comparable in terms of its themes and Modisane's preoccupations to Eva Hoffman's memoir suggestively titled Lost in Translation (1989). Besemeres' (9) incisive commentary on Hoffman's memoir could apply equally to Modisane's autobiography: "Hoffman's metaphor of self-translation offers insights into the nature of relations between language, culture and selfhood which are a broad theoretical and experiential interest, illuminating the condition of what I call 'language migrants' and native speakers alike".

As I hope to show, Modisane's autobiographical narrative is built around typical pre-liberation South African racial stereotypes, where blackness denotes lack of political power, dignity and self-respect, as well as the denial of civil rights that people take for granted in free societies. On the other hand, whiteness denotes the power for self-actualisation - the freedom to realise one's true potential or, to put it simply, to be truly free. At a very deep level, the metaphor of whiteness in Modisane's book stands for true humanity. Modisane suggests that in a country where black people are victims of all sorts of dehumanising policies and practices, to be "truly human" is to be "white". In his thoroughly illuminating analysis of Fanon's ideas on the psychology of race, Lewis Gordon (24) comments as follows on what he describes the apparently antithetical relationship between constructions of blackness and whiteness: "Antiblack racism presents whiteness as the 'normal' mode of 'humanness.' So, the black reasons, if blackness and whiteness are constructed, perhaps the black could then live the white construction, which would reinforce the theme of constructivity. Each portrait is, however, a tale of how exercising this option leads to failure."

Because he had a high school certificate and could speak English, Modisane, like other writers and journalists of his time, thought of himself as educated and thus civilized. This loaded concept defines the narrator-protagonist of Modisane's 
autobiography, who personifies the paradoxical notion of a "civilized black man". In his book Black Skin, White Masks (1967) Frantz Fanon captures Modisane's dilemma accurately in his deceptively simple (some might even say simplistic) characterisation of race relations between the white settlers and the colonised black people: "There is a fact: White men consider themselves superior to black men. There is another fact: Black men want to prove to the white men, at all costs, the richness of their thought, the equal value of their intellect." (12)

For the black man, proving his value means, at a very basic level, mastering the language of the coloniser and the culture that goes with it. What is implicit in Modisane's autobiography is that he has met both requirements: he thinks and speaks English and regards Western culture as his own; so why can't he be a white man? Regarding the issue of mastering the English language, we return to Fanon (17): “To speak means to be in a position to use a certain syntax, to grasp the morphology of this or that language, but it means above all to assume a culture, to support the weight of a civilization."

As Modisane constantly reminds the reader, he wishes to be "white", and is highly ambivalent regarding-if not plainly dismissive of - the physical and apparently inescapable condition of his blackness. Evidently, for Modisane (218) the notion of whiteness goes beyond the denotative meaning referring to skin pigmentation, as he puts it:

I want acceptance in the country of my birth, and in some corner of the darkened room I whisper the real desire: I want to be accepted into white society. I want to listen to Rachmaninov, to Beethoven, Bartok and Stravinsky; I want to talk about drama, philosophy and social psychology; I want to look at the paintings and feel my soul touched by Lautrec, Klee and Miro; I want to find a nobler design, a larger truth of living in literature. These things are important to me, they are the enjoyment of a pleasure I want to share.

The disjuncture between the freedom and emotional contentment afforded by the fruits of Western culture enumerated by Modisane here, and the inescapable reality of his blackness, is strikingly captured in the title of the autobiography: Blame Me on History. The title is deliberately ambiguous but could be taken to imply that the author failed to live a rewarding and fulfilling life in South Africa, and that this failure is a direct consequence of historical circumstances beyond his control: had he been born in a free country, he would have been white, the argument seems to go.

As he tells us in his autobiography, Modisane's need to acquire white friends to whom he would demonstrate his "intelligence" and his palate for Western art became an obsession bordering on neurosis. It is this almost neurotic preoccupation with proving his value to the white world that provides the rationale for writing Blame Me on History: 
But I am a freak, I do presume an appreciation for Western music, art, drama and philosophy; I can rationalise as well as they (educated whites) and using their own system of assumptions, I presume myself civilised and then set about to prove it by writing a book with the title, Blame Me on History which is an assumption that if I am a freak it should not be interpreted as a failure of their education for a Caliban, but a miscalculation of history. (178-9)

Modisane's autobiography is a narrative act not only of self-analysis but also of selfjudgement or even self-castigation. In the autobiography Modisane feels the need to explain himself to his readership which, significantly, happens to be white and European. In simple terms he seems to be saying, "if I failed to become a well-known writer, art connoisseur and intellectual, the history of my country should take the blame and not me". This is stated explicitly in one of the early chapters of the book:

I could perhaps present eloquent argument that in a normal society I could have made this or that of my life. Perhaps all of us in South Africa have reason to blame the hypocrisy, the race attitudes, the dangerous state of race relations, on the colour-bar; there are even those who see it as a sequence of history, we have been committed by history to this condition. (217)

Modisane's life history is not just his story but the story of the South Africa of his time. Thus six chapters in the book deal with apartheid legislation such as the Group Areas Act, the Population Registration Act and the Separate Amenities Act. Modisane offers brief personalised commentary on these laws and their cumulative effect on his freedom as an individual as well as their effect on black people as a whole. The extent to which South African black autobiographies are a record of the history of apartheid merits a full study on its own.

One strategy Modisane used to deal with the problem of identity and his need to embrace the illusory state of whiteness was to get involved in love affairs with women. His sexual conquests of white women represented a symbolic entry into the white world that rejected him. He is candid enough to tell us that his marriage failed because his wife, Fiki Plaatjie, was black:

I am able to admit that my marriage decomposed because Fiki is black, the women in the sex pilgrimage left me in a coma of screaming loneliness because they were black. They need not have failed me or done anything, the fact they were black was sufficient supposition that they were not good enough, only the state of being white could satisfy me, and in a tedious succession I thought myself to be [...] lyrically involved with every white woman I met. I was poetically in love with Ruth, then with Frankie, and with Mira, Erika, [...] There was the inevitable moment of recognition when the white woman becomes white and the black man is actually black. (220) 


\section{Metaphors of Self}

Two relatively distinct theoretical constructs of selfhood are evident in Modisane's autobiography: namely, the communal self (the author as social being) manifested in those events in the book in which Modisane identifies himself as a member of the community of Sophiatown; and what I call the aesthetic-intellectual self, which manifests itself in Modisane's persistent search for intellectual and artistic fulfilment. Both these representations of the self are, in essence, what James Olney would describe as "metaphors of self", as they are mere projections of the primary self, which is the overall organising consciousness in the autobiography. The so-called primary self is itself a metaphor, as the real self is neither accessible to nor completely knowable by either the reader or the autobiographer. Perhaps the best way to conceptualise the nature and functioning of human consciousness in Blame Me on History is that suggested by John Claude Curtin (344): "Consciousness is not only intentional but also reflexive. The reflexive dimension of consciousness functions as a kind of diastolic gathering together of intentional multiplicity. Consciousness as reflexive knows itself inchoately in all of its intentional developments. Consciousness as reflexive also seeks to preserve its transcendental unity throughout all of its intentional incarnations."

It could be argued that at the core of Modisane's autobiographical self-identity is a transcendental, contemplative and analytical self, which is capable of rising above the limitations of his material conditions and weaving a fairly coherent narrative of selfidentity. The narrator-protagonist of Modisane's autobiography draws the reader's attention to the inherent contradictions, gaps and inconsistencies in translating the condition of blackness into whiteness. The following rather intriguing passage alerts us to Modisane's existential dilemma:

My little room in Sophiatown was a fly-over which connected the two worlds, in which I erected all the symbols of the world which rejected me: on the walls were hanging reproductions of Lautrec, Van Gogh, Chagall, Klee and Miro, there were books and folders of the Impressionists unobtrusively lying about; the cabinet was stocked with cocktail glasses, wine, brandy and beer glasses discreetly paraded, and those of my African friends were meant to be impressed by the ritual of making American martinis served in chilled cocktail glasses before meals, wine with meals and after meals drinks in fresh glasses. All this was done for the pleasure of hearing them say, Bloke you're a white man; why not, if I could not be white physically and legally, I could pretend a white existence. (254)

The process of self-translation described here is not only symbolic but has obvious literal or practical dimensions as well. Modisane is not making up the incidents he describes about his almost obsessive desire to become white; he literally changed his lifestyle to conform to his understanding of what it meant to be white in the South 
Africa of the 1950s. This is confirmed by his contemporaries, some of whom were his colleagues on Drum magazine (see Mphahlele; Nicol and Nkosi, "Introduction"). As mentioned earlier, Modisane went out of his way to acquire white friends who would recognise him as an "intelligent native". His description of his first white friend, whom he met while working as a messenger in a bookshop in Johannesburg, is revealing, to say the least:

It was at the bookshop where I made my first transcolour friendship; Phillip Stein and I were the same age, he had been to university, was a poet and completely non-political [...] Phillip's friendship was free, there was no question of nursing the sensibilities of the poor, under-privileged Native; I need not have read Plato or understood, and appreciated, art, music and drama, to be recognised by him as an intelligent Native. But we did have literature in common, each hoped for a far richer and more satisfying triumph in writing, and a result more fundamental and astounding; he wrote poetry and I tried my hand at prose. (85-6, emphasis added)

In spite of the obvious, literal ways in which the words "black" and "white" are used in Modisane's autobiography, it is worth pointing out that these loaded concepts could be seen as metaphors that Modisane uses to give meaning to his experience. In his book, aptly titled Metaphors of Self, James Olney reminds us of the inherently elusive nature of the autobiographical self and the power of metaphor to capture its manifestations:

The self expresses itself by the metaphors it creates and projects, and we know it by those metaphors; but it did not exist as it now does and as it now is before creating its metaphors. We do not see or touch the self, but we do see and touch its metaphors: and thus we "know" the self, activity or agent, represented in the metaphor and the metaphorizing. (30)

It could be argued that in Blame Me on History the "metaphorizing" is synonymous with symbolic translation, in which the author's metaphors of self oscillate between the condition of literal blackness and symbolic or metaphoric whiteness. The theme of symbolic transformation into a state of whiteness runs through the autobiography. Modisane sees himself as being trapped in his blackness both symbolically and literally. This is evident in the incident in which he describes his reaction to witnessing his mother insulted and humiliated by white policemen:

I was helpless in the coffin of my skin and began to resent the black of my skin, it offered no protection to my mother from the delinquency of the police constables who saw only the mask representative of a despised race; but Ma-Willie was not black, she was my mother, and if I had been white the whiteness of my skin would have protected her honour. I wished I was white. (36) 
Unlike in the earlier passage, it is evident that Modisane is using "white" and "black" both literally and metaphorically here. In creating a relationship between experience and identity, black intellectuals of the apartheid era knew that they were, in the words of Fanon, not only black, but black in relation to the white man. Lewis Nkosi, Modisane's colleague on Drum, describes in Home and Exile this process as follows:

I know that in my case I first discovered my Africanness not, as one might imagine, when I discovered I was black. I took my colour quite for granted. I discovered Africanness the day I discovered that I was not only black but non-white. The difference between being black and also being considered non-white could scarcely escape anyone sensitive enough. (186)

\section{Contradictions of liberal individualism}

The organising principle in Modisane's autobiography seems to be the ideology of individual liberalism associated with the white world from which he is excluded. Thus, another important form of translation in Modisane's story of his life is to be found in what seems to have been his deliberate decision not to take part in collective activities aimed at ending apartheid. The narrator of Blame Me on History is very sceptical of the value of collective action that takes the form of political activism, and for this reason finds it difficult to associate himself with the campaigns of either the African National Congress (ANC) or the Pan Africanist Congress (PAC). He chooses, instead, to be an intellectual and an artist who is above politics. This decision is directly traceable to the ideology of liberal individualism associated with Western culture, which Modisane seems to have unquestioningly embraced as his own. Modisane has chosen the discourse of liberalism to construct his autobiographical self. Throughout his autobiography he is at pains to demonstrate that he is an individual with distinctive personal qualities, interests and talents.

Thus, in Blame Me on History we are constantly reminded of the conflict between public obligations (which are of a recognisably political nature) and the writer's private interests. Modisane believes that the "objectivity" and inherent idealism of bourgeois art (including literature) could afford him the intellectual freedom he fervently desired as a person with a highly developed artistic sensibility; but for the perceptive Modisane this position also has its contradictions, as indicated in his reaction to Phillip Stein's advice that he should devote himself to 'creative writing':

[...] I was too personally involved in the dynamics of being black in South Africa, I could not intellectually shrug off the oppression, the cruelty, the injustice, as though it were a careless trifle; I lived with it twenty-four hours a day, every day of my life, I could not be an uncommitted and disinterested spectator; yet I knew Phillip was right, knew that I had to re-educate myself into believing in myself, into an acceptance of the objectivity of art, the inalienable persuasion of philosophy, the principles of freedom and equality. Subjectivism was, however, emotionally more persuasive: oppression, poverty, and 
personal humiliation cannot be wholly experienced vicariously, or something one can be intellectual about; one can perhaps only sympathise, nothing more. (86, emphasis added)

Modisane appears to have turned to creative writing only as a strategy for coping with the alienation and frustration engendered by living in a materially deprived environment. As he explains, the need to explore his creative talent emerged out of the internal contradictions that characterised his social and political roles as a communal being:

I directed my energy to my writing, determined to use it as the weapon for gate-crashing into the worlds which rejected me; my writing showed a studied omission of commitment, the histrionics of tight-fisted protest, and in my first published short story, The Dignity of Begging, I created a satirical situation in which I sat back and laughed at the worlds which rejected me. (88)

Modisane examines the plight of being 'handicapped' by one's skin colour, and strategies for coping with this 'deformity'. During a period of disillusionment with the political strategies of the ANC, Modisane again turned to the intellectual and emotional haven of creative writing:

I burned my Youth League membership card and retreated into a political wilderness. I was disillusioned beyond reconciliation, and decided to separate my life and interests from politics, until there shall rise from out of the slum of African politics a new and more professional liberation movement. (139)

Yet, as Modisane himself admits, there was no way of escaping the reality of being black in a society where people are judged according to their skin colour:

BUT I am black, because I am black I was a piece of the ugliness of Sophiatown and a victim of the violence of white South Africa; I became an unwilling agitator trapped in the blackness of my skin, and because I am black I was forced to become a piece of the decisions, a part of black resistance. I wanted to be both black and unconcerned with the games at politics, but a non-committed African is the same black as a committed Native. Intellectually I resisted involvement with political parties, rejected attempts to be drawn into political discussions, yet my physical being became a tool of the decisions of the African National Congress. There was no choice, during riots the police shot their rifles and sten guns at anything which was black. (140)

\section{Conclusion}

Modisane's autobiography is a classic example of a situation of the colonised native, which has been aptly and tellingly described by Tsitsi Dangarembga as a "nervous condition", in her autobiographical novel of that title. Patrick Lenta's comments (103) are strikingly apposite in this regard: 
A major theme of Blame is the attempt to construct the colonized subject's consciousness by gaining his mental assent to colonialism's foundational doctrine of "white [ness] as the sovereign law and black[ness] as its transgression" (Parry 1987: 28). Involved in this project is the shaping of black subjectivity through the discriminatory classifications of legal discourse and through representations of the inferiority of the racial Other that the colonized is manipulated into internalizing.

Clearly challenging 'colonialism's foundational law' as the narrator-protagonist in Blame Me on History does results in mental disorientation and perpetual anxiety. Modisane's nervous condition takes the form of an extreme case of schizophrenia that he has attempted to tackle through the art of self-narration. Thus, for Modisane, the writing of the story of his life must have had important historical and therapeutic functions.

It is difficult to say whether he succeeded in reality in transforming himself into a citizen of the world. On a physical and practical level, Modisane must have believed that leaving South Africa on an exit permit, as he did in 1959, would help him to come to terms with his nervous condition and afford him the opportunity of creating himself anew, as it were. He first went to Britain, where he worked for the BBC for a while. He later moved to Germany, where he died in Dortmund in 1986. Significantly, he was survived by his white German wife

\section{Works Cited}

Besemeres, Mary. Translating One's Self: Language and Selfhood in Cross-Cultural Autobiography. Oxford: Peter Lang, 2002.

Curtin, John Claude. "Autobiography and the dialectic of consciousness." International Philosophical Quarterly 14 (1974): 343-6.

Dangarembga, Tsitsi. Nervous Conditions. London: Women's Press, 1988.

Fanon, Frantz. Black Skin, White Masks. Trans. Charles Lam Markmann. London: Pluto Press 1986.

Goldsmith, Meredith. "Of masks, mimicry, misogyny, and miscegenation: forging black South African masculinity in Bloke Modisane's Blame Me on History." Eds. Lahucine Ouzane and Robert Morrell. African Masculinities: Men in Africa from the Late Nineteenth Century to the Present. Scottsville: UKZN Press, 2005.

Gordon, Lewis. What Fanon Said: A Philosophical Introduction to His Life and Thought. Johannesburg: Wits UP, 2015.

Lenta, Patrick. "Law, subject de/formation and resistance in Bloke Modisane's Blame Me on History." Current Writing: Text and Reception in Southern Africa. 22.2 (2011): 101-8.

Masemola, Michael Kgomotso. "Between Tinseltown and Sophiatown: The double temporality of popular culture in the autobiographical cultural memory of Bloke Modisane and Miriam Makeba." Journal of Literary Studies 27.1 (2011): 1-27.

Modisane, Bloke. Blame Me on History, Johannesburg: Ad Donker, 1986 [1963].

Mphahlele, Eskia. “Bloke Modisane: A Tribute to a Great Artist." Staffrider 6.4 (1987): 33.

Ngwenya, Thengani Harold. "The ontological status of Self in autobiography: The case of Modisane's Blame Me on History." Current Writing: Text and Reception in Southern Africa 1.1 (1989): 67-76.

Nicol, M. A Good-looking Corpse. London: Minerva, 1995.

Nkosi, Lewis. Home and Exile. London: Longman, 1965. . Introduction to Blame Me on History. London: Penguin, 1990.

Olney, James. Metaphors of Self: The Meaning of Autobiography. Princeton: Princeton UP, 1972.

Sanders, Mark. Complicities: The Intellectual and Apartheid. Pietermaritzburg: U of Natal P, 2002. 